\title{
OPPORTUNITIES FOR REALIZATION OF THE AUTONOMY IN SPORT
}

\author{
Vasil Dimitrov \\ National Sports Academy "Vassil Levski”, Sofia, Bulgaria
}

\begin{abstract}
The study examines topical issues on the autonomy in sports and the normative mechanisms for regulation. The uneven nature of sporting relationships, which are subject to regulation of sport law, predetermines the different nature of regulation, which in turn provides for a different "autonomy" of sports organizations. In order to solve the main tasks, the achievement of the goal and the proof of the hypotheses, a method of literary sources and content analysis was applied.

The study examines topical issues related to sport autonomy as well as regulatory mechanisms for regulation. The aim of the research is to reveal some legal and sociological aspects of the autonomy in sport and the particularities of a manifestation on a national and global scale.

The following objectives are the following: to reveal and analyze interpretations and variations related to the term autonomy in sport from a legal and sociological point of view; To draw conclusions and recommendations on the theory and practice of sporting activities with a view to preventing deviant behavior in sport. Conclusions: The desire to have a large part of the norms should be replaced with clear rights, obligations and responsibilities. The current law on sport largely fails to meet today's demands for sport.
\end{abstract}

Key words: public regulation, management methods, regulation, sport.

\section{INTRODUCTION}

The casual character of relationships in sport which are subject to regulation of sport law predetermine different kind of regulation, which in turn presupposes different "autonomy" of sports organizations. The problems concerning the autonomy of sports entities on the one hand are insufficient means in the public sector for sport from other corruption and organized meetings in sport. The study examines actual issues related to sport autonomy as well as regulatory mechanisms for regulation.

The term autonomy derives from the ancient Greek independent, someone who gives himself his own right", it is associated with synonyms such as self independence, autonomy, self-rule of a community [ ${ }^{1}$ http://lib.sportedu.ru].

According to Koleva (1997), „in general, the existence of rights and the ability of a social subject (group, organization, and individual) to organize and direct their actions independently within the social entity to which they belong". From a sociological point of view, autonomy can be interpreted in the context of the concept of determinism or social order.
Thomas Hobbes explains the problem of social order as follows: man is a human being whose behavior in the short life of his existence is determined by some inherent qualities of human nature - rivalry, distrust, and the pursuit of power. Although people were born and die equal, as a result of their behavior there is inequality in society and they live in this context of social inequality. Because of rivalry, mistrust and aspiration to power that are the natural state of people's lives is „War of Everyone Against Everyone". These prerequisites raise the question: how is it possible that these social organization and order has been established and maintained constantly and what basis they are created on? (Hobbes, 1971).

The contemporary situation of sociological knowledge assume that the problem of social order could be formulated in the following way: how can durable and adjustable social relations between social actors who have opposite interests and different resources be created, operated, preserved and changed (Tsonev, 2013; Barazgova, 1997; Ivanov, 1989).

In summary, the term social order can be seen as well-established rules and mechanisms for coordinating roles and institutions. And the concept of so- 
cial role as a combination of prescriptions in terms of rights and obligations outlining the boundaries of human behavior as corresponding to a particular position or the so-called status (Dimitrova, 2017).

The scientific analysis, according to Fotev (2004), reaches the autonomy of the structure that is experienced and experienced in terms of everyday life by individual and collective agents (natural/ physical persons and juridical persons). According to value or consensus theories, the main mechanism for the maintenance of social order in society is socialization (Kolarova, 1997), which is primary and secondary.

The principle of autonomy in sport applied by public authorities, according to a number of authors dealing with legal regulation in sport, is one of the most important principles which the whole system of sport is built on (Ng, 2010; Mazzucco, 2010).

The term autonomy in sport emerged in 1949 in the Olympic Charter and has a direct impact on national Olympic committees (Chappelet, 2009). According to Jacques Roger, Chairman of the International Olympic Committee (2001-2013), the protection of autonomy in sport is fundamentally important because it is based on the unique nature of sport, on commonly accepted principles such as fair play and competitiveness at global level. International organizations active in the sphere of sport can be divided into organizations with general and specific competence. The organizational division in the sphere of sport is realized through different regulation in the sphere of: social, stores and travel relationships.When they relate to sports. Also sports law regulates the activity of all main legal entities:

1. Gender as a physical subject of the law

2. Organizations of citizens as legal entities

3. State and local authorities

4. International sports organizations - institutions.

In summary, the organizational division is implemented through sport law and governs the regulation of sporting social relations, from public authorities and sports organizations, the realization of this regulation as rights and obligations and the legal order in the field of sport. It should not be forgotten that the unnecessary interference by the public authorities could easily break the principles of sport (Pigeassou, Garrabos, 1997).

\section{Objective And Tasks Of The Study}

The aim of the scientific research is to reveal some legal and sociological aspects of the autonomy in sport and some features of their manifestation on national and global scale. The idea of autonomy consists in requiring a person to obey only those norms that he himself gives or at least voluntarily accepts as reasonably justified.

The aim of this publication is to enhance the theoretical and practical knowledge and competencies of real and potential users (specialists, students, sportsmen).

The specific objectives are the following:

$\checkmark$ to reveal and analyze interpretations and varieties related to the term autonomy in sport from legal and sociological point of view;

$\checkmark$ determine the main negative trends influencing the studied problem;

$\checkmark$ identify good practices relevant to the autonomy in the field of sports;

$\checkmark$ to draw conclusions and recommendations on the theory and practice of sports activities in order to to prevent deviant behavior in sport (it is not necessarily that sports organizations have autonomy but within the law).

\section{Study hypotheses:}

$\checkmark$ we assume that the research will reveal various problems and variations related to the term autonomy in sport and its peculiarities of manifestation on national and global scale;

$\checkmark$ we assume that the scientific work will contribute to the improvement of the theoretical and practical knowledge, the legal awareness of citizens and officials, and the acquisition of skills to use the rule of law.

In order to resolve the main tasks, the achievement of the goal and the proof of the hypotheses, a method of study of literary sources and content analysis was applied.

Content analysis is the most appropriate method to determine changes in social values and norms, in images and stereotypes of the "other" (Diekmann, 1998). The method goes beyond the text and focuses on the social context, the social norms and values transmitted through the text. Understanding social roles and patterns of behavior mastering 
forms, values, symbols, norms, traditions, languages, meanings and other cultural values; acquiring own socio-cultural experience and personal (social, ethnic, professional, etc.) identity; achieving autonomy and autonomy in the individual's individual behavior. They are marked by reading texts and compared with those expressed in other texts. "Content-analysis is a specific technology (include an analysis of policy measures) for detailed document study and quantification of its content" (Mateeva, 2002). The technology include an analysis of policy measures.

The research was conducted between May 2015 and April 2019.

\section{RESULTS AND DISCUSSION}

In general, the normative level is represented by two forms of regulation of the people's social actions: institutional and non-institutional. They are also valid for the field of sports as a whole with their specifics but also act in parallel at it and at social level.

According to Stepanenko (Stoichev, 1996, pp. 1733), there are two types of norms: universal, which are accepted by all members of society without restrictions, and special ones that regulate the activities of the individual groups.

It is typical for universal norms that they rely on prescriptions and requirements directly related to the generally separable system of values and often have a legal, legislative basis. In sport have a special law governing sporting relationships - a sports law, and these norms are complemented by organizational frameworks for specific procedures and include:

$\checkmark$ principles of functioning, differentiation and interdependence of different sports associations;

$\checkmark$ principles of participation, roles' distribution and change of positions;

$\checkmark$ rules on remuneration and punishments, success and defeat;

$\checkmark$ offset the effort on the way to its own sports goals.

Special regulations refer to certain social and professional groups such as youth, teachers, coaches, doctors, and others (according to the national classifier have different requirements).
In sports, the laws and codes of conduct of individual disciplines that control the behavior of the contestants and partners are analysed, and the general principle is often presented as a collection of methanorms. These may be so-called Olympic values and goals, but they also include the old Scout slogan ,to consider life as a game, and the world as a playground“ (Albonico et al., 1971).

According to André-Noël Schaeke, autonomy in sport is one of the three key principles in this field, followed by solidarity and the principle of partnership between public authorities and sports organi-

zations (Chappelet, 2010; Chappelet, 2009).

The legal interpretation of autonomy is linked to the competence and the possibility of creating legal norms for itself and its field of activity, as well as the possibility to develop its own normative acts regulating the activity [ ${ }^{2} \mathrm{http} / / / \mathrm{mpes}$.government.bg].

According to Marcus F. Mazukko, problems relating to the international autonomy of sports organizations have purely academic interest as long as the rules and work of international sports organizations enter into conflicts of interest with national laws, then these issues emerge as having practical significance (Latty, 2007).

After 1990 the change of the political model of government in Bulgaria and the emerging crisis in the country, sport clubs became autonomous as for example the shop, previously there was a monopoly of the state and in sport. There has been an opportunity to register under the Commercial Act as Joint Stock Companies which were created. This has brought many sports clubs to the brink of survival, and governing of sports federations has been associated most often with authoritarian and not so democratic governance, corruption and scrutiny.

Corruption in FIFA has already been proven, inform world agencies. Former vice president of the headquarters, Juan Angel Naput, and former president of the Brazilian Football Confederation, José María Marin, were found guilty by the New York court.

They have taken bribes in exchange for awarding marketing and media rights to international football matches [ ${ }^{3} \mathrm{https}: / /$ topsport.bg/other-football/ koruptsiyata]. 
According to National Strategy for the Development of Physical Education and Sport in the Republic of Bulgaria 2012-2022, the main strategic goal of the system is promotion of physical education, sport and social tourism as means of improving the health and physical capabilities of population, increasing the number of those practicing organized sports for all, as well as raising the world's sports prestige of Bulgaria $\left[{ }^{4} \mathrm{http}: / /\right.$ rechnik.info].

There have arised several questions about autonomy, especially about the autonomy of sport itself. What is the mechanism of autonomy and, therefore, what is the legal basis for this autonomy?

There has been paid an insufficient attention in Bulgarian legislation to the considered issues under. In terms of current law on sport, the state encourages the creation and the functioning of sports organizations. If there is a special law, it is logical that all these sports organizations have been registered (can be registered under the trade law and by law for non-profit legal entities).

On one hand, we have a non-profit organization with additional requirements in the Physical Education and Sport Law (Serdiukov, 2010; Zakon za fozicheskoto vaspitanie i sporta, 2016).

The sport's strategy provides legal changes guaranteeing differentiated minimum size of each citizen's financial sum for sport. The autonomy of sport is again not on the agenda.

The question of the autonomy of sport in Bulgaria and not only in our country is relevant for number of reasons, and it is so because we have witnessed many questionable or arranged matches. First of all whether it has or is only legally regulated under the law, and secondly, great autonomy leads to violation or circumvention. The question raise and the answer emerged, and we ask where is this autonomy or directly it is missing? According to Jean Cornell, this is just a kind of cover for business interests in the entertainment industry and sports (Bach, 2009).

Other authors are not so extreme in their opinions and have stated that sport today is losing its traditional role and autonomy (Rogge, 2010). As a prerequisite for the autonomy of sport, some authors such as Idroten believe that sport should have its own independent judiciary system based on the principles of democracy (Idrotten, 2005). Serdyukov draws attention to the fact that the autonomy of sport is also related to the existence of specialized agents acting in resolving disputes in this area, which are so-called "special competence" (Serdiukov, 2010). This is also the work of Ponkina titled „Autonomy of Sport“ (Ponkina, 2013).

That the independence of sport is guaranteed by sporting arbitrage, which is also a fundamental principle of regulation of sports organizations (Chappelet, 2009, pp. 267-268).

Margulis (2005) argues that the issue of autonomy has also been linked to the fact that sports courts imposing disciplinary sanctions or ruling on disputes are final or can be contested in a Court of common jurisdiction. Sports courts can be heard by arbitrators sport and by a court of general jurisdiction.

Some sports developing primarily amateur sports must be protected with rules that encourage visits to their competitions and events. For example, their sports calendars have to be arranged with television programmes so that competitions will be broadcasted instead of other TV and radio programmes in order to attract attention of spectators and listeners and promote the sport.

The World Football Association (FIFA) has put into use a website where players, judges and club officials can report suspicions of match fixing.

FIFA has announced that all such suspicions can be reported to bkms-system.net/FIFA and the Ethics Committee investigator Michel Garcia will directly access the information. The site is already active. This is part of the Black Lot's new strategy. On bkms-system.net, anyone can write a suspicious match letter $\left[{ }^{5} \mathrm{https}: / / w w w . b l i t z . b g /\right.$ sport/ svetoven-futbol].

As necessary measures, changes can be made to the rules governing the training of athletes in the country. To allow all sports to develop it should be used all sports facilities and thus contribute to the development of youth and sport so that sports clubs play an important role in cities and villages and thus improve and encourage the training of young players and increase the development of sports. This devel- 
opment should also be linked to strict control effectuated by sports organizations.

We have to examine again the legal nature of autonomy in sport and as its basic prerequisites, we can distinguish:

$\checkmark$ the specific structure of sport;

$\checkmark$ own standards based on the principle of Fair Play;

$\checkmark$ an effective principle of dialogue between public authorities and non-governmental organizations developing sport; (an enhanced role for non-governmental organizations and special investigative bodies, such as the specialized criminal court, for example);

$\checkmark$ prevention of deviant behavior.

Respecting the autonomy of sport means achieveing, its goal when the relevant rules are constantly and voluntarily observed (Gambelunghe, 2005).

The imperative statement can be considered bilaterally: as a condition for political and ideological independence, and as a mechanism for preserving the autarchy and independence of sport. Autonomy is a means of achieving the goal, not an end in itself (Ng, 2010). It is by preserving its autonomy that sport has the opportunity to develop and perform its social functions.

We support Zahari Zahariev's (2015, pp. 16) view that relationships in sport are not explicitly regulated as the basic right of the citizen (as, for example, the labor right or the right for personal correspondence and others). As text we have some regulation in primary public acts in the Constitution Art. 52 paragraph 3, obliges the State to promote sport (chapter „Basic rights and obligations of citizens") (Konstitucia na Republika Bulgaria).

The encouragement of sport led to a coming light in a tunnel from a counter-incoming train. It is precisely the absence of obligation concerning the State's support the reason that led to this situation where the State from a promoter have to become a manager with corresponding responsibilities which is one of the reasons for the current state. Well not exactly the reference field covered part of the sport brought to light in the tunnel of a counter coming train, on the one hand it has the other simulates the activity
On the other hand, sport law is positioned as a sub-sector of civil law, and the basic principle that is applied in it is the principle of equality - the dispositive principle, which is directly related to autonomy of sports organizations (Zahariev, 2016; Povil, 1999; Zahariev, 2015).

Sport is bound to be politically neutral but sport can not be apolitical (Bach, 2009). The imperative state or mandatory can be seen as a condition for the economic independence of sport. It is difficult to give a clear answer in the field of sport, who has the supremacy - whether it is local law or sports law. It all depends on the specifics of the public relations under consideration and the specific subject of regulation. It is also logical that the degree of autonomy in sport may be different (Foster, 2000).

Bruno Niels, Olaf Walvar, Loginus Koch, we also consider case-law relevant to the issue at hand against the international federation of the Cycling Federation were the subject of an inquiry on the interpretation of Articles 7, 48 and 59 of the Treaty and of Regulation (EEC) No 1612/68 on freedom of movement of workers in the Community (OJ L $257,19.10 .1968$, p. 2) [6 http://eur-lex.europa.eu].

The Court's decision was that, in view of the Community's objectives, the practice of sport is subject to Community law in so far as it constitutes an economic activity within the meaning of Article 2 of the Treaty.

Such solution is also found in the Gaetano Dona case against Mario Mantero. Subject to Articles 7, 48 and 59 of the EEC Treaty, in the operative part of its judgment the court refers to rules or national practice, even if adopted by a sports organization restricting the right to participate in football matches as professional or semi-professional players only for nationals of the Member State in question are incompatible with Article 7 [7 http://eurlex.europa.eu].

The Bosmon judgment states: ,The immediate effect of Article 48 of the EEC Treaty can not be relied on in support of claims for transfer, training or development benefit which have already been paid at the date of the present judgment; is still due under an obligation that arose prior to that date, with the exception of entities who before that date brought an action or made an equivalent claim under the 
applicable national law" [8 http://curia.europa.eu]. Changes the legislation in Europe subsequently to this and the governors of the fifa and the head and subsequently applies also in Bulgaria.

The limits of autonomy in sport do not mean total independence and complete freedom without rules (Latty, 2007).

Those of the broadcasters so that during their competitions they will not broadcast any other on television and radio to attract visits and popularize the sport. Reasons for the current state. On the other hand, sport law is positioned as a sub-sector of civil law and the basic principle that is applied in it is the principle of equality, the principle of the dispositive principle, which has a direct bearing on the autonomy of sports organizations.

According to the Greek Vice-Minister of Culture and Sports, Yiannis Ioannides, shared at the 11th "Council of Europe" Conference (Athens, Greece, 11-12.12.2008), „we have to give answers to the main questions in order to define the limits of the autonomy of sport, as well as to determine the cases in which the state has to intervene" [ $\left.{ }^{9} 41\right]$.

In the case of Meca Medina and Igor Majcen v FINA and IOC the Commission in 2006 and in the case of Lehtonen against the Belgian Basketball Federation, the Court of Justice of the European Union establishes the necessary balance between recognizing the authentic nature of sporting activities and the basic principles of the legal system of the European Union, with a significant reduction in the scope for sport as "exclusivity“ (in the sense of common rules) $\left[{ }^{10} \mathrm{http}: / /\right.$ curia.europa. Eu; ${ }^{11} \mathrm{http}: / /$ www.olympic.org; ${ }^{12}$ http://www.olympic.org]. According to the European Charter of 1992, sports organizations have the right to make decisions independently, but within the framework of the law $\left[{ }^{13}\right.$ https://europa.eu].

\section{CONCLUSION}

As a result of the study of legal and sociological literature on the autonomy of sport, the hypotheses raised are generally confirmed.

Transition societies are characterized by the disintegration of the old regulatory system and, at the same time, the instability of the new regulatory system and its corresponding institutions. In such a situation there is a crisis in social integration. People follow a "new" morality, their values and motives are different.

Willingness, which is characteristic of the large part of the norms, should be replaced with clear rights, obligations and responsibilities. The current law on sport largely fails to meet today's demands for sport.

A complex and interdisciplinary approach is needed to identify and overcome deviant behavior in sport at different levels, as well as strengthened formal and informal control by State and non-governmental organizations working in this field.

\section{REFERENCES:}

Albonico, R., Pfister-Binz, K. (1971). Sociolgie des sports theoretische und methodische Grundlagen, Bazel.

Bach, T. (2009). Unity in diversity - Respect, Responsibility, Reliability, XIII Olympic Congress (Copenhagen, 2009), Proceedings, Belmont sur Lausanne (Switzerland): Lautrelabo S.à r.l., 2010. P. 108-112. http://www.olympic.org/Documents/Congress 2009/XIII, (accassed 20 February 2016).

Barazgova, E. (1997). Amerikanska sociologia, Tradicii i sovremennost, Ekateringburg, Bishkek.// Баразгова, Е. (1997). Американская соииология, Традиции и современность, Екатеринбург, Бишкек.

Chaker, A. (1999). Study of national sports legislation in Europe Strasbourg: Council of Europe Publishing, pp. 22.

Chappelet, J. (2009). For negotiated autonomy of sport XIII Olympic Congress. Contributions. Belmontsur Lausanne (Switzerland): Lautrelabo S.à r.l.,. pp. 267268.

Chappelet, J. (2010). Lautonomie du sport en Europe. Strasbourg: Editions du Conseil de l'Europe, p. 11.

Conev, S. (2013). „Sociologia na sporta“, working paper, NSA „Vasil Levski“.

Corneloup J. (2002). Les théories sociologiques de la pratique sportive. Paris: Presses Universitaires de France, p. 155.

Diekmann, A. (1998). Empirische Sozialforschung. Grundlagen, Methoden, Anwendungen. (4.durchgel. Ausg.). Reinbeck: Rohwolt. pp. 483).

Dimitrova, A. (2017). Sociology of sport, Uchebnik, NSA PRES, Sofia. (In Bulgarian).

Foster, K. (2000). Can sport be regulated by Europe? An analysis of alternative models. Professional sport in 
the EU: Regulation and Re-regulation /A. Caiger, S. Gardiner. The Hague: T. M. C. Asser Press, pp. 43-64.

Fotev, G. (2004). Dialogichna sociologia, Iztok-Zapad, Sofia, pp. 454-462. (In Bulgarian).

Gambelunghe C. (2005). La responsabilita del professionista sportivo: Università degli studi di Perugia; p. 3-4 at: http://www.rdes.it/tesi_gambelunghe.pdf./ (accassed 03 April 2016).

Glashev, A., M. Minaev, Chaban, N. (2002). Sportivnoe pravo, М., pp. 6-7, 136.// Глашев, А., М. Минаев, Н. Чабан (2002), Спортивное право, М., с. 6-7, 136.

Hobbes, T. (1971). Leviatan, Bulgarsko izdanie, predgovor, Nauka i izkustvo, Sofia. (In Bulgarian).

Idrotten, V. (2005). Expected Sport, Stockholm, p. 29.

Ivanov, N. (1989). Sociologia segodnia, М.// Иванов, Н. (1989), Социология сегодня, М.

Kolarova, R. (1997). „Socialen red“. In Enciklopedivhen rechnik po sociologia, Vtoro izdanie, BAN, Institut po sociologia, „M-8-M“, Sofia, 394-395. (In Bulgarian).

Koleva, S. (1997). „Avtonomia“, Tilkidjiev, N. In Enciklopedivhen rechnik po sociologia, Vtoro izdanie, BAN, Institut po sociologia, „M-8-M“, Sofia, 14-15. (In Bulgarian).

Konstitucia na Republica Bulgaria. Obn. DB. br. 56 ot 13.07.1991, v sila ot 13.07.1991, izm. i dop., br. 85 ot 26.09.2003 izm. i dop., DB. br. 18 ot 25.02.2005, br. 27 ot 31.03 .2006 , br. 78 ot 26.09 .2006 - Reshenie № 7 na Konstituconnia sad ot 2006, br. 12 ot 6.02.2007, izm. i dop. DB. br. 100 ot 18 December 2015. (In Bulgarian).

Latty, F. (2007). La lex sportiva: recherche sur le Droit transnational/ Préface de Jacques Rogge,avant-propos d'Alain Pellet, Leiden (The Netherlands), Boston (USA): Martinus Nijhoff Publishers, XXI, p. 417.

Mateeva, S. (2002). Izsledvane na komunikaciite i obshtestvenoto mnenie, Blagoevgrad, 202. (In Bulgarian).

Margulis, M. (2005). Normotvorchestvo korporatibnih obedinenii v oblasti sporta: M., s. 12. // Маргулис, M. (2005). Нормотворчество корпоративных объединений в области спорта: М., с. 12.

Morariu, O. (2009). The autonomy of the Olympic Movement in thecontext of globalisation XIII Olympic Congress (Copenhagen, 2009), Contributions, Belmont sur Lausanne (Switzerland): Lautrelabo S. à r. 1.,. pp. 278.

Mazzucco, M. (2010). Lex sportiva: Sports law as a transnational autonomous legal order: Thesis University of Victoria, Victoria (British Columbia, Canada), pp. 2-3.

Ng, S. (2010). XIII Olympic Congress (Copenhagen, 2009), Proceedings, Belmont sur Lausanne (Switzerland): Lautrelabo S. à r. 1.,. pp.112.

Pigeassou, C., Garrabos, C. (1997). Management des organisations de services sportifs Paris: Presses universitaires de France, pp. 34;

Ponkina, A. (2013). Avtonomnost sporta: Teoretiko-pravovoe izsledovanie/ Komissia po sportivnomy pravu Associacii iuristov Rosii; Nacionalnoe obedinenie sportivnih iuristov Rossiiskoi Federacii. - M., 2013. - s. 102 (Seria: „Aktualnie problemi sportivnogo prava“. Vip. 17).// Понкина, А. (2013). Автономность спорта: Теоретико-правовое исследование/ Комиссия по спортивному праву Ассоциации юристов России; Национальное объединение спортивных юристов Российской Федерации. - М., 2013. - c.102 (Серия: «Актуальные проблемы спортивного права». Вып. 17).

Povil. P. (1999). Sportni federacii. Praven regim, IK „Propeler", Sofia. (In Bulgarian).

Rogge, J. (2010). Speech from the IOC, World Olympic Sport Convention, Acapulco, at http://www.olympic.org/ (accassed 23 November 2010).

Serdiukov, A. (2010). Sportivnoe pravo kak kompleksnaia otrasl zakonodatelstva: Dis: /GU VSH. M., s. 161162.// Сердюков, А. (2010). Спортивное право как комплексная отрасль законодательства: Дис:/ ГУ ВШЭ. М., c.161-162.

Stoichev, A. (1996). Sociologia na sporta, NSA PRES, Sofia, pp. 17-33. (In Bulgarian).

Stridh, A. (2009). Idrottens juridifiering $\mathrm{i}$ ett EU rättsligt perspektiv, at http://www.jus.umu.se/digita1Assets/52/52921_anders-stridh-ht09.pdf./ (accassed 06 August 2016).

Zakon za fizicheskoto vaspitanie i sporta, Obn. DB. br. 58 ot 9 July 1996, izm. DB. br. 43 ot 7 June 2016. (In Bulgarian).

Zakon za uridicheskite lica s nestopanska cel, Obn. DB. br. 81 ot 6 October 2000., izm. DB. br. 103 ot 27 December 2016. (In Bulgarian).

Zahariev, Z. (2015). Actualni problemi na publichno pravni regulacii v upravlenieto na sporta, Sport \& nauka, izvanreden broi № 1, 16. (In Bulgarian).

Zahariev, Z. (2016). Sbornik normativni dokumenti, NSA PRES, Sofia. (In Bulgarian). 


\section{ENDNOTES}

1 http://lib.sportedu.ru/GetText.idc?TxtID=1542/ (accassed 3 July 2016).

2 http://mpes.government.bg/Documents/Documents/Strategii/Strategia_2012-2022.pdf/ (accassed 12 June 2016).

3 https://topsport.bg/other-football/koruptsiyata-vavfifa-veche-e-dokazana.html (accassed 12 December 2017).

4 http://rechnik.info/ (accassed 3 July 2016).

5 https://www.blitz.bg/sport/svetoven-futbol/sayttza-koruptsiya-na-fifa-veche-raboti_162793.html (accassed 13 July 2017).

6 http://eur-lex.europa.eu/legal-ontent/FR/ TXT/?uri=CELEX:61974CJ0036/ (accassed 12 October 2016).

7 https://europa.eu/european-union/about-eu/institutions-bodies/eu/ (accassed 1 July 2016).

8 http://curia.europa.eu/jcms/upload/docs/ application/pdf/2009-10/tra-doc-bg-arret -c-0415-1993-200802177-05_00.pdf/ (accassed 1 July 2016).

9 https://europa.eu/european-union/about-eu/institutions-bodies/eu/ (accassed 1 July 2016).

10 http://curia.europa. eu: La Rochefoucauld, de E. Recueil de jurisprudence en matiere sportive / Commission Sport et Droit // 228 Arrêt de la Cour de justice (sixième chambre) de 13 avril 2000 dans 1‘Affaire № C-176/96 «Jyri Lehtonen et Castors Canada Dry Namur-Braine ASBL c. Fédération royale belge des sociétés de basket-ball ASBL/ (accassed 10 May 2016).

$11 \mathrm{http}: / /$ www.olympic.org/Documents/Reports/FR/ fr_report_264.pdf./ (accassed 26 September 2016).

12 http://www.olympic.org/Documents/Reports/FR/ fr_report_264.pdf.См.:La Rochefoucauld, de E. Recueil de jurisprudence en matiere sportive / Commission Sport et Droit/ (accassed 12 October 2016).

$13 \mathrm{https}$ ://europa.eu/european-union/about-eu/institutions-bodies/eu/ (accassed 1 July 2016). 